\title{
SUNFLOWER SEED GERMINATION AND STORABILITY RESPONSE TO CHEMICAL DESICCATION
}

\author{
Petar Čanak ${ }^{*}$, Milan Jocković1, Bojana Vujošević ${ }^{1}$, Milosav Babić ${ }^{1}$ \\ Bojan Mitrović ${ }^{1}$, Dušan Stanisavljević ${ }^{1}$, Vladimir Miklič́c
}

\begin{abstract}
The objective was to assess the effect of chemical desiccation on seed germination and storability in three sunflower female inbred lines and to point at possible indicators for optimal performance time. Desiccation was performed with Diquat $\left(21 \mathrm{ha}^{-1}\right)$ applied at 7-day intervals from the end of flowering to harvest maturity. There were 6 treatments and control (untreated). Germination was tested 2 and 21 months after harvest. The highest germination was recorded when the desiccation was performed 35 days after flowering. Results showed that optimal moment for applying chemical desiccation when there is no negative effect on the seed germination is specific for each sunflower genotype. Seeds with a high level of germination (>90\%) can be stored for 19 months without significant loss in germination, namely, it was not negatively affected by chemical desiccation. Seed moisture and growing degree-days can be used as reliable indicators for optimal desiccation time.
\end{abstract}

Key words: desiccation, germination, seed moisture, storability, sunflower

\section{Introduction}

Desiccation as an agrotechnical measure has been introduced in agricultural practice several decades ago, with the goal of accelerating plant drying which would ensure that the crop is ready for an early harvest. The measure is advantageous in cool climates where spring crops often mature in late fall, in time when weather conditions are unfavourable for harvest (Miklič et al., 2001). By drying out green portions of the plant, chemical desiccation makes mechanized harvesting easier (Miklič et al., 2012). Desiccation is especially beneficial in seed production of crops such as sunflower (Čanak et al., 2011) and soybean (Zuffo et al., 2019). The optimal moment for performing desiccation is at physiological maturity when seeds reach maximal viability and vigour. Harvesting before reaching physiological maturity could shorten grain filling period, reduce seed size or affect its chemical composition (Kappes et al., 2012; Albrecht et al., 2013). Determination of physiological maturity is of essential importance, and different indicators such as seed moisture (Kaya et al., 2004; Miklič et al., 2006; Vallejos et al., 2011), maximum dry weight (Vallejos et al., 2011) and oil content (Kaya et al., 2004) can be used as guidelines. However, since the environmental factors highly influence sunflower development, heat unit summation (growing degree-days) is commonly used for measuring the time between phenological stages and for maturity classification (Kaya et al., 2004, Baum et al., 2019). 
Desiccation can be performed with a range of desiccants that differ in their mode of action. In sunflower desiccation, Diquat is frequently used. This desiccant diverts energy from photosynthesis and induces production of peroxide radicals, causing cell damage and desiccation (Esfahani et al., 2012; He et al., 2015).

In seed used for cultivation, the percentage of germination is one of the most important characteristics (Kumar et al., 2011). Germination is a complex process which starts with the uptake of water and is completed with the appearance of the radicle. In an agronomical sense, it refers to seedling emergence from the soil (Nonogaki et al., 2010).

Another important characteristic of cultivated seed is its storability. Seed storability refers to the ability of the seed to be stored for a prolonged period of time without loss of viability and is affected by the harvest stage. This seed characteristic is important not only from the point of managing seed stocks in seed companies but also impacts the effectiveness of seed preservation in gene banks (Babić et al., 2015).

Objective of this study was to assess the effect of chemical desiccation on sunflower seed germination and storability, and to point at possible indicators for determining optimal performance time.

\section{Materials and methods}

Testing was carried out using three female inbred lines of sunflower (designated as G1, G2 and G3) developed at Institute of Field and Vegetable Crops, Novi Sad, Serbia. There were 6 desiccation treatments and control. Desiccation was performed with herbicide Reglone forte (Diquat $150 \mathrm{~g} \mathrm{l}^{-1}$ ) with a dose of $2 \mathrm{l} \mathrm{ha}^{-1}$, applied at 7-day intervals from the end of flowering (DAF-days after flowering) to harvest maturity. Desiccant was applied with a knapsack sprayer. Basic plot size was $22.4 \mathrm{~m}^{2}$. The control for each genotype was taken from untreated plants in harvest maturity.

Seed samples from several sunflower heads were collected directly before each desiccation treatment in order to test the moisture content in seed at the time of treatment. Seed moisture was determined in the laboratory by the conventional gravimetric method. When harvest maturity was reached (seed moisture $\leq 11 \%$ ), 12 heads were taken from each treatment for analysis. The analysis of seed oil content was performed by the Soxhlet method. Meteorological data were received from the local meteorological station. Growing degree-days (GDD) for each day were calculated using the following equation:

$$
\mathrm{GDD}=\left(\mathrm{T}_{\min }+\mathrm{T}_{\max }\right) / 2-\mathrm{T}_{\mathrm{b}}
$$

where $\mathrm{T}_{\min }$ is minimal daily temperature, $\mathrm{T}_{\max }$ is maximal daily temperature and $\mathrm{T}_{\mathrm{b}}$ is base temperature. Base temperature for sunflower development of $8^{\circ} \mathrm{C}$ was determined according to Bazin et al., (2011). The cumulative degree-days were then determined by summing the daily degrees from the end of flowering to harvest maturity.

Germination was tested 2 and 21 months after harvest, while in between the two testing dates seed was stored in storage under uncontrolled conditions. The test was conducted in six replicates of 50 seeds on soil substrate in the greenhouse at a temperature of about $25^{\circ} \mathrm{C}$, with regular irrigation. Germination was counted after 10 days (ISTA, 2018).

For determining the effect of desiccation date on germination, the first testing date was considered, whereas the effect of desiccation date on seed storability was assessed based on differences in the germination of both testing dates. Data were analyzed using 3-factorial analysis of variance. Means were compared using LSD test at the 5\% level of significance. With the purpose of determining possible indicators of optimal desiccation time, germination percent was regressed on GDD, seed moisture and seed oil content for every genotype (Table 1). Polynomial (quadric) regression was the most suitable. For statistical analysis software, Statistica 10 was used. 
Table 1. Growing degree-days (GDD), seed moisture and seed oil content at different desiccation dates (DAF-days after flowering) of sunflower genotypes (G1, G2 and G3)

Tabela 1. Suma aktivnih temperatura, sadržaj vlage semena i sadržaj ulja u različitim momentima desikacije (DAF-dana posle cvetanja) genotipova suncokreta (G1, G2 i G3)

\begin{tabular}{|c|c|c|c|c|c|c|c|}
\hline \multirow{2}{*}{$\begin{array}{l}\text { Desiccation } \\
\text { date }\end{array}$} & \multirow{2}{*}{$\begin{array}{l}\text { GDD } \\
\left({ }^{\circ} \mathrm{C}\right)\end{array}$} & \multicolumn{3}{|c|}{ Seed moisture (\%) } & \multicolumn{3}{|c|}{ Seed oil content (\%) } \\
\hline & & G1 & G2 & G3 & G1 & G2 & G3 \\
\hline $7 \mathrm{DAF}$ & 98.50 & 69.30 & 75.50 & 74.41 & 35.66 & 29.56 & 32.52 \\
\hline $14 \mathrm{DAF}$ & 198.40 & 59.15 & 57.10 & 59.69 & 43.73 & 35.87 & 39.04 \\
\hline $21 \mathrm{DAF}$ & 289.40 & 44.00 & 42.33 & 50.47 & 41.56 & 41.40 & 43.45 \\
\hline $28 \mathrm{DAF}$ & 404.50 & 11.85 & 24.44 & 30.41 & 40.77 & 39.68 & 45.57 \\
\hline $35 \mathrm{DAF}$ & 503.20 & 11.19 & 13.45 & 24.15 & 37.24 & 40.29 & 46.38 \\
\hline $42 \mathrm{DAF}$ & 581.10 & 9.59 & 8.29 & 17.55 & 37.73 & 40.34 & 46.99 \\
\hline Control & 664.90 & 9.38 & 8.96 & 8.61 & 37.03 & 39.89 & 46.83 \\
\hline
\end{tabular}

\section{Results and discussion}

Effect of desiccation date on germination was determined using the first testing date (after 2 months). The highest mean germination of each genotype was obtained at desiccation date $35 \mathrm{DAF}$, and no significant difference in germination was observed afterwards (Table 2).

In the genotype G1, at 28 DAF seed moisture was $11.85 \%$ (Table 1 ), and from that moment onwards, no significant increase of germination was recorded. At that time plants already reached harvest maturity and chemical desiccation was no longer economically justified.
In the genotype G2, the stability of germination was determined from the treatment 35 DAF, at seed moisture of $13.45 \%$. However, since high germination level $(>90 \%)$ was reached already at $28 \mathrm{DAF}$, at seed moisture of $24.44 \%$, chemical desiccation could have been performed at that time.

In G3, no significant difference in germination was determined among treatments 35 DAF (at the seed moisture of $24.15 \%$ ), the subsequent treatment and control.

Furthermore, in all tested genotypes no significant difference was registered between treatments with the highest germination and the control. These results suggest that when

Table 2. Germination (\%) of sunflower genotypes (G1, G2 and G3) at different desiccation date (DAF-days after flowering) and testing date

Tabela 2. Klijavost (\%) genotipova suncokreta (G1, G2 i G3) u različitim momentima desikacije (DAF-dana posle cvetanja) i testiranja

\begin{tabular}{lcccccccc}
\hline \multirow{2}{*}{$\begin{array}{c}\text { Desiccation } \\
\text { date }\end{array}$} & \multicolumn{4}{c}{ After 2 months } & \multicolumn{5}{c}{ After 21 months } \\
\cline { 2 - 9 } 7 DAF & 78.0 & 86.7 & 51.7 & 72.1 & 72.3 & 78.3 & 63.3 & 71.3 \\
14 DAF & 80.3 & 88.7 & 69.7 & 79.6 & 72.0 & 76.3 & 65.7 & 71.3 \\
21 DAF & 78.7 & 87.0 & 90.0 & 85.2 & 79.0 & 88.0 & 82.3 & 83.1 \\
28 DAF & 81.7 & 91.3 & 86.3 & 86.4 & 75.0 & 90.7 & 84.7 & 83.4 \\
35 DAF & 85.0 & 97.0 & 92.3 & 91.4 & 79.0 & 95.3 & 93.7 & 89.3 \\
42 DAF & 80.3 & 93.3 & 92.0 & 88.6 & 82.3 & 95.7 & 93.7 & 90.6 \\
Control & 85.3 & 94.7 & 93.7 & 91.2 & 90.0 & 95.0 & 97.7 & 94.2 \\
Mean & 81.3 & 91.2 & 82.2 & 84.9 & 78.5 & 88.5 & 83.0 & 83,3 \\
\hline
\end{tabular}

LSD (P=0.05); T = 1.217; D x T = 3.219; G x D x T = 5.576; T-testing date; D-desiccation date; G-genotype 
sunflower reaches a certain stage of maturity, chemical desiccation has no negative effect on germination. Szemruch et al. (2017) indicate that optimal time for chemical desiccation of sunflower can be when the moisture content is in the range of $27-30 \%$. On the other hand, Kaya et al. (2004) consider that sunflower seed reaches physiological maturity when the moisture content is between $30-40 \%$. Miklič et al. (2001) reported that germination was the highest when desiccation was performed at seed moisture of $45 \%$ (21 DAF). These different results from other authors and results from our work suggest that the optimal moment for desiccation could be specific for each sunflower genotype.

The effect of desiccation date on seed storability was assessed based on differences in germination on both testing dates. Comparing the mean values of two testing dates, a significant decrease of germination after the storage period was recorded (Table 2).

However, comparing the mean values from each desiccation date individually, only at desiccation date 14 DAF significant germination decrease after the storage period was determined. When each genotype was individually observed, different results were obtained. Significant reduction in germination in genotype G1 was determined at treatments 7 DAF, 14 DAF, 28 DAF and 35 DAF. This can indicate that genotype G1 can be stored without loss in germination from the treatment $42 \mathrm{DAF}(9.59 \%$ seed moisture) when it has reached harvest maturity. In genotype G2 there was no significant reduction of germination during storage period from the treatment $21 \mathrm{DAF}$, onward. Seed moisture at that time was $42.33 \%$. Mahesha et al. (2001) reported that early harvest may accelerate the loss of viability during storage compared to conventional harvest dates. In the genotype G3, significant reduction of germination after the storage period was determined only at the treatment 21 DAF. Storage of this genotype from the treatment $28 \mathrm{DAF}$, at seed moisture of $30.41 \%$, onwards, didn't cause germination loss during the storage period. After reaching high germination, storage period did not significantly affect the germination of the tested genotypes, leading to the conclusion that seeds with high germination level (>90\%) can be stored for 19 months without significant loss in germination. In agreement with this, Deshmukh et al. (2004) reported that seeds harvested at physiological maturity had the highest germination throughout the storage period.

\section{G1}

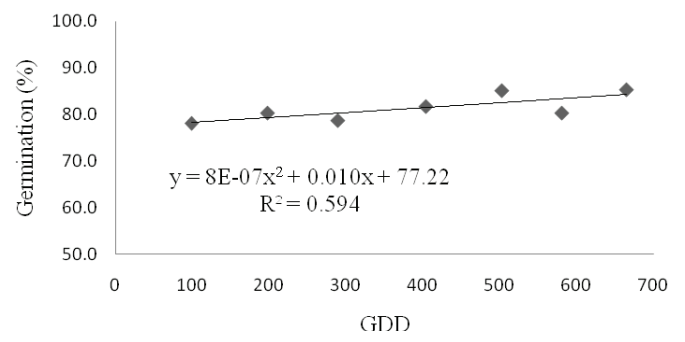

G2

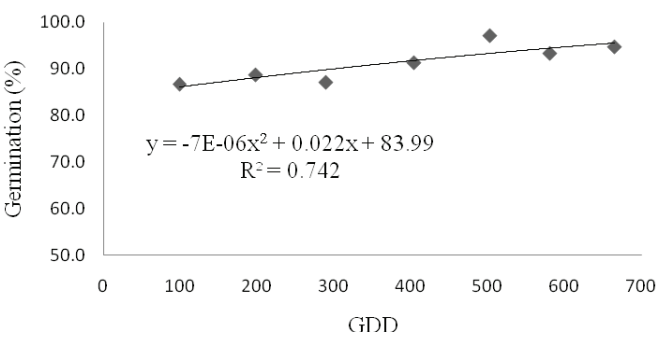

G3

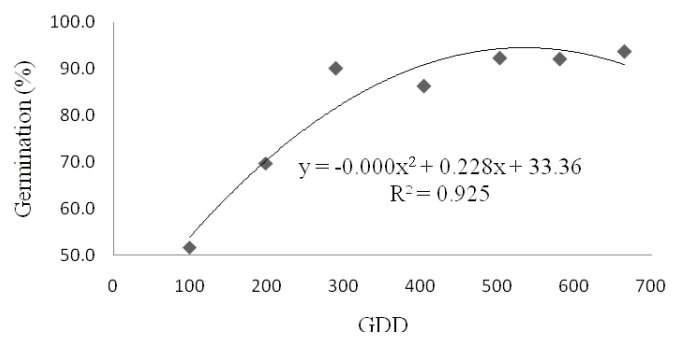

Figure 1. Regression analysis of growing-degree days (GDD) effect on germination percentage of sunflower genotypes (G1, G2 and G3)

Grafikon 1. Regresiona analiza uticaja sume aktivnih temperatura na klijavost genotipova suncokreta (G1, G2 i G3)

Possible indicators for optimal desiccation time were analyzed using regression analysis and showed a different trend with respect to the seed germination. Different response in germination on the same indicators in analysed genotypes was also recorded. When GDD was 
increasing, the germination percentage also increased (Figure 1). The GDD accounted for $59.4 \%, 74.2 \%$ and $92.5 \%$ of accompanying response in germination in genotypes G1, G2 and G3, respectively.

With decreasing seed moisture, germination percentage was increasing (Table 1, Figure 2). Regression analysis showed that the seed moisture accounted for $56.6 \%$ to $91.3 \%$ of the variation in germination in the analyzed genotypes. Miklič et al. (2006) reported that coefficients of determination (germination by the seed moisture) in sunflower ranged from $72 \%$ to $96 \%$.
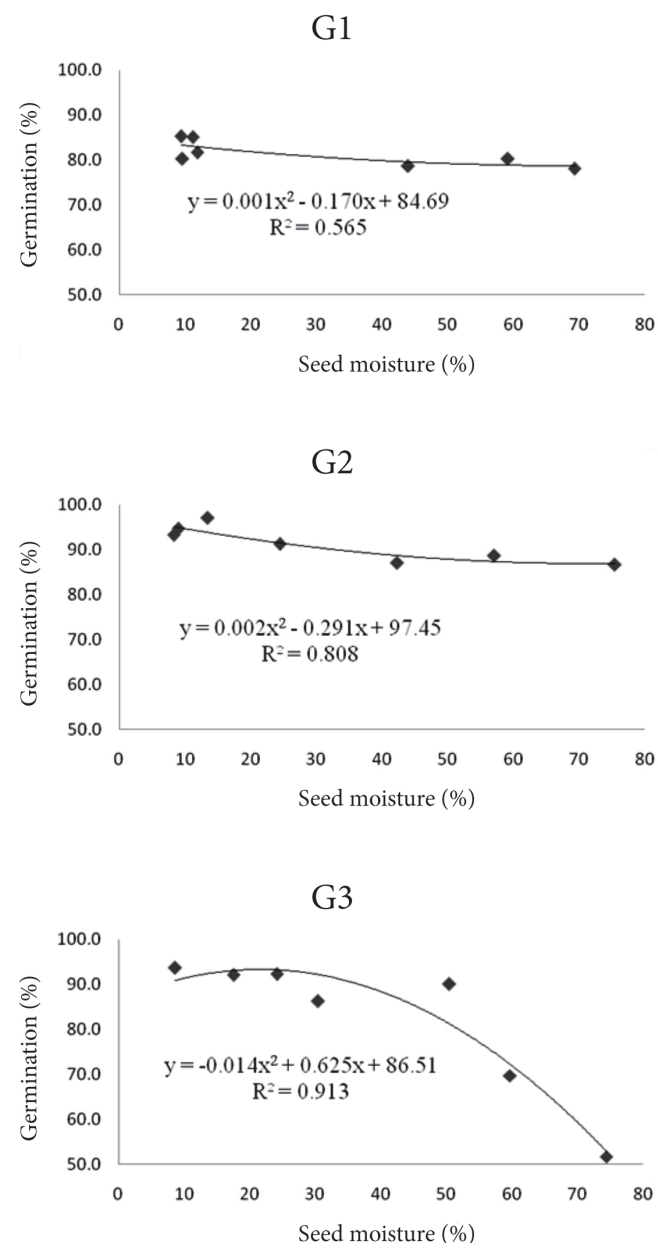

Figure 2. Regression analysis of seed moisture effect on germination percentage of sunflower genotypes (G1, G2 and G3)

Grafikon 2. Regresiona analiza uticaja sadržaja vlage u semenu na klijavost genotipova suncokreta (G1, G2 i G3)

Trend lines of seed oil content effect on germination had similar direction as GDD, with an exemption of G1 where the trend line was slightly convex (Figure 3). In genotypes, G1 and $\mathrm{G} 2$ very low percentage of variation in germination was explained with seed oil content (16.5\% and $32.1 \%$ ). However, in genotype G3 seed oil content had a high response in germination $(96.5 \%)$.

G1

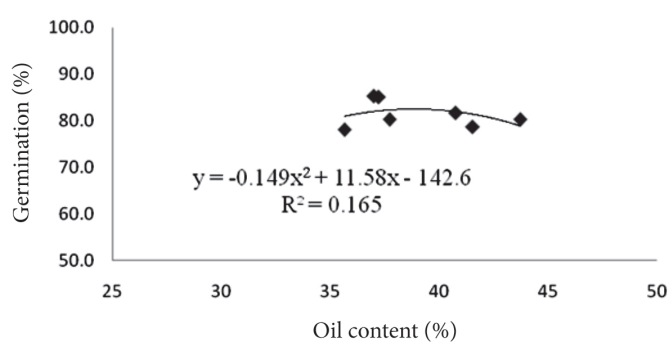

G2

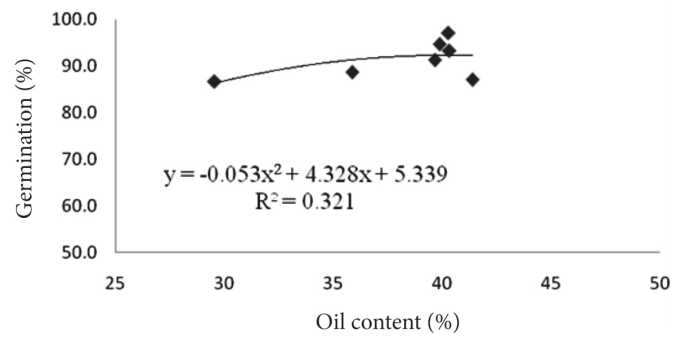

G3

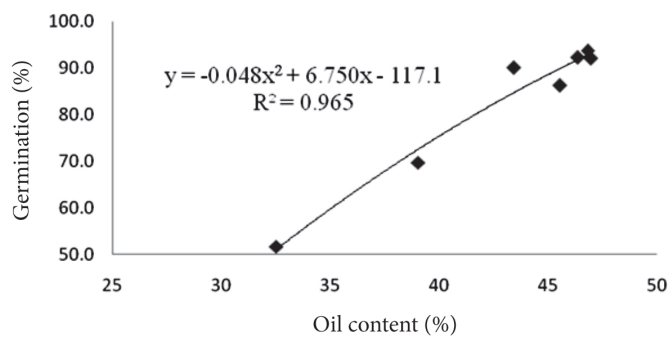

Figure 3. Regression analysis of seed oil content effect on germination percentage of sunflower genotypes (G1, G2 and G3)

Grafikon 3. Regresiona analiza uticaja sadržaja ulja u semenu na klijavost genotipova suncokreta (G1, G2 i G3)

Coefficients of determination determined in the analysis of seed moisture and GDD effect on germination were in a similar range. Influence of seed oil content on germination was 
lower and with a higher variation. Determination of these indicators is fast and simple which is of practical importance. The results presented herein indicate that GDD and seed moisture are more reliable indicators of the optimal time for desiccation than seed oil content.

\section{Conclusion}

Chemical desiccation performed in the optimal moment doesn't have a negative effect on seed germination. This optimal moment is specific for each sunflower genotype. Seeds with a high level of germination (>90\%) can be stored for 19 months without significant loss in germination, namely, it was not negatively affected by chemical desiccation. Seed moisture and growing degree-days in sunflower can be used as reliable indicators of the optimal time for chemical desiccation.

\section{References}

Albrecht LP, Krenchinski FH, Placido HF, Bomm MAR, Kunz VL, Korber ÂHC, Bieler RR (2013): Canola desiccation at different stages of pods maturation. Revista Brasileira de Herbicidas, 12 (2): 143-150.

Babić V, Kravić N, Babić M, Popović A, Ivanović D (2015): Viability testing of maize landraces accessions from MRIZP gene bank. Rom. Agric. Res., 32: 85-91.

Baum ME, Archontoulis SV, Licht MA (2019): Planting date, hybrid maturity, and weather effects on maize yield and crop stage. Agron. J., 111 (1): 303-313.

Bazin J, Batlla D, Dussert S, Maarouf-Bouteau H, Bailly C (2011): Role of relative humidity, temperature, and water status in dormancy alleviation of sunflower seeds during dry after-ripening. J. Exp. Bot., 62 (2): 627-640.

Čanak P, Radić V, Mrdja J, Jocković M, Ćirić M, Miklič, V (2011): Effect of desiccation moment on 1000-seed weight in sunflower. Field and Vegetable Crops Research, 48: 391-396.

Deshmukh DG, Mohod VK, Rathod TH, Patil BN, Tayade AM, (2004): Storability of sun- flower seeds as influenced by time of harvest. Annals of Plant Physiology, 18: 76-78.

Esfahani M, Fardi M, Asghari J, Rabiei M, Samizadeh, H (2012): Effects of pre-harvest application of parquat on grain moisture reduction, grain yield and quality of rapeseed (Brassica napus L.) cultivars. Caspian J. Environ. Sci., 10 (1):75-82.

He Y, Cheng J, Liu L, Li X, Yang B, Zhang H, Wang Z (2015): Effects of pre-harvest chemical application on rice desiccation and seed quality. J. Zhejiang Univ. Sci., B 16: 813-823.

ISTA (2018): International Rules for Seed Testing, International Seed Testing Association, Bassersdorf, Switzerland

Kappes C, Arf O, Arf MV, Ferreira JP, Alcalde AM, Portugal JR (2012): Produtividade de feijoeiro de inverno submetido à dessecação com paraquat na pré-colheita. Rev. Ceres., 59: 56-64.

Kaya Y, Baltensperger D, Nelson L, Miler J (2004): Determining physiological maturity time in sunflower. Trakya University Journal of Science, 5: 1-10.

Kumar B, Verma SK, Singh HP (2011): Effect of temperature on seed germination parameters in Kalmegh (Andrographis paniculata Wall. ex Nees.). Ind. Crops and Prod., 34: 1241-1244.

Mahesha CR, Channaveeraswami AS, Kurdikeri MB, Shekhargouda M, Merwade MN (2001): Storability of sunflower seeds harvested at different maturity dates. Seed Research, 29: 98-102.

Miklič V, Mrdja J, Modi R, Jocić S, Dušanić N, Hladni N, Miladinović D (2012): Effect of location and harvesting date on yield and 1000-seed weight of different sunflower genotypes. Rom. Agric. Res., 29: 219-225.

Miklič V, Crnobarac J, Joksimović J, Dušanić N, Vasić D, Jocić S (2006): Effect of harvest date on seed viability of different sunflower genotypes. Helia, 29: 127-134.

Miklič V, Dušanić N, Crnobarac J (2001): Effect of desiccation date on some parameters of quality in hibrid sunflower seed. Zbornik radova Instituta za ratarstvo i povrtarstvo, 35: 251-258. 
Nonogaki H, Bassel GW, Bewley JD (2010): Germination-Still a mystery. Plant Sci., 179: 574-581.

Szemruch CL, Cantamutto MA, García FA, Aguirre M, Renteria SJ, Rondanini DP (2017): Hybrid sunflower seed yield, composition and deterioration after chemical desiccation. Int. J. Plant Prod., 11 (2): 225240.

Vallejos M, Rondanini D, Wassner DF (2011): Water relationships of castor bean (Ricinus communis L.) seeds related to final seed dry weight and physiological maturity. Europ. J. Agronomy, 35: 93-101.

Zuffo AM, Santos M, Oliveira IC, Alves CZ, Aguilera JG, Teodoro PE (2019): Does chemical dessication and harvest time affect the physiological and sanitary quality of soybean seeds? Rev. Caatinga, 32 (4): 934-942. 


\title{
EFEKAT HEMIJSKE DESIKACIJE NA KLIJAVOST I ČUVANJE SEMENA SUNCOKRETA
}

\author{
Petar Čanak, Milan Jocković, Bojana Vujošević, Milosav Babić, \\ Bojan Mitrović, Dušan Stanisavljević, Vladimir Miklič
}

\begin{abstract}
Sažetak
Cilj rada bio je da se ispita uticaj hemijske desikacije na klijavost i čuvanje kvaliteta semena tri inbred linije suncokreta, kao i da se ispitaju mogući indikatori za optimalno vreme izvođenja desikacije. Za desikaciju je korišćen Dikvat (2 1/ha) u intervalima od 7 dana od završetka cvetanja do žetvene zrelosti. Obavljeno je 6 tretmana i kontrola. Klijavost je ispitivana 2 i 21 mesec nakon žetve. Najveća klijavost je zabeležena pri desikaciji 35 dana posle cvetanja. Rezultati pokazuju da je optimalni momenat za izvođenje hemijske desikacije, u kom nema negativnog uticaja na klijavost, specifičan za svaki genotip suncokreta. Seme visokog kvaliteta (>90\%) moguće je čuvati 19 meseci bez značajnog smanjenja klijavosti, takođe, kod takvog semena nije bilo ni negativnog uticaja hemijske desikacije. Vlaga semena i sume aktivnih temperatura se mogu koristiti kao pouzdani indikatori optimalnog vremena za izvođenje hemijske desikacije.
\end{abstract}

Ključne reči: čuvanje kvaliteta semena, desikacija, klijavost, suncokret, vlaga semena

Primljen: 07.10.2020.

Prihvaćen: 01.12.2020. 